\title{
Graft Versus Host Disease
}

National Cancer Institute

\section{Source}

National Cancer Institute. Graft Versus Host Disease. NCI Thesaurus. Code C3063.

A reaction, which may be fatal, in an immunocompromised subject (host) who has

received an antigenically incompatible tissue transplant (graft) from an

immunocompetent donor. The reaction is secondary to the activation of the

transplanted cells against those host tissues that express an antigen not expressed by

the donor, and is seen most commonly following bone marrow transplantation; acute

disease is seen after 5-40 days, and chronic disease occurs weeks to months after transplantation. 